\title{
SWOT Analysis of Sustainable Marketing Mix of Food Industry Enterprises
}

\author{
TOMASZ TROJANOWSKI \\ Department of Management \\ Jan Kochanowski University in Kielce \\ Żeromskiego Street 5, Kielce 25-369 \\ POLAND
}

\begin{abstract}
The article is a pioneering attempt to identify the strengths and weaknesses as well as opportunities and threats to the development of a sustainable marketing mix in Polish food industry enterprises. The study enriches the poor state of literature on the sustainable marketing and marketing mix. The value of research is to acquire and present new knowledge about the four elements of marketing mix in the sustainable concept. The article may support managers who want to implement the concept of sustainable marketing mix in their companies. The aim of the study is to conduct a SWOT analysis, identifying strengths, weaknesses as well as opportunities and threats to the development of a sustainable marketing mix in Polish food industry enterprises.
\end{abstract}

Key-Words: SWOT analysis, sustainable marketing mix, food industry enterprise

Received: February 2, 2021. Revised: September 8, 2021. Accepted: September 19, 2021. Published: September 30, 2021.

\section{Introduction}

The processes of environmental degradation and emerging social problems put the welfare and prosperity of the next generations at risk. The development of modern civilization, the desire for industrial enterprises, including those from the food sector, to have more and more material and financial resources, means that the natural resources of the Earth are rapidly shrinking and, in some cases, completely disappearing. The changing economic environment of food enterprises, which is related not only to the development of civilization, but also to the increase in competition, technology development, or common consumerism, observed mainly in developed and developing countries, strongly affects the functioning of enterprises [1]. The manufacturing activity of food industry enterprises is obviously related to the impact on the natural environment of man. Taking the Earth's natural resources needed for production is an unquestionable interference with the ecosystem of our planet. The business activity of enterprises, which ignores the environmental and social aspects, is doomed to failure in the long term. For this reason, there is a need to change the current way of managing enterprises, including marketing activities, into more environmentally and socially sustainable economic ventures.
An effective solution to meet the emerging environmental and social problems is the reorganisation of production processes towards more sustainable and responsible manufacturing activities [2]. For this reason, food sector companies should make efforts to change their current production activities into pro-environmental and pro-social activities [3]. One of the main conditions for reorienting the philosophy of conduct of food companies to date is a properly understood and professionally conducted sustainable marketing mix.

\section{The Concept of Sustainable Marketing Mix}

The concept of sustainable development gave foundations to the formation of a new scientific trend known as sustainability marketing. A. Pomering and L. W. Johnson claim that in the last decade there has been an increased interest in the issues of sustainable marketing, including the sustainable marketing mix, among scientists and researchers [4].

As a result of the recognition of the state of knowledge in the field of sustainable marketing, including the sustainable marketing mix, it should be indicated that this is 
a new and developing scientific area that requires further analysis in terms of theoretical and empirical aspects. They deal with the subject of sustainable marketing: D. Fuller; F. Belz, K. Peattie; K. Leitner; D. Kadirov; D. Martin, J. Schouten; B. Emery; J. Kemper, C. M. Hall, P. W. Ballantine [5-11]. When referring to the achievements in the field of sustainable marketing mix in relation to food industry enterprises, the publications by $\mathrm{E}$. Rudawska; T. Trojanowski; P. T. Kazibudzki, T. Trojanowski, should be suggested [1, 12-13]

The sustainable marketing mix of food industry companies includes four instruments of marketing impact on customers - a sustainable product [14-15], a sustainable price [16-17], sustainable distribution [18-19] and sustainable promotion mix [20]. Proper management of the marketing mix elements by managers of food industry enterprises is associated with achieving not only financial benefits, but also social and environmental advantages.

A balanced marketing composition is important for the success of the business on the market because it directs the organisation's activities not only to the sale of products, but also to meeting the needs of buyers who are not indifferent to social and environmental aspects. The use of marketing mix instruments supporting sustainable development by food industry enterprises is particularly important because production processes significantly affect the condition of the natural environment, thus contributing to environmental and social problems. The concept of a sustainable marketing mix assumes the introduction to the market of food products that will be able to properly meet the needs and desires of buyers, while having a minimum impact on the natural environment.

\section{Research Methods}

Research carried out in this article concerns food industry enterprises. The aim of the study was to identify strengths and weaknesses as well as opportunities and threats to the development of sustainable marketing mix in Polish food industry enterprises. In order to carry out the SWOT analysis, information on the actual state of the phenomenon under study was collected.

The conducted research used the method of personal interview, the advantage of which is high credibility, ensured by the possibility of asking questions directly related to the studied phenomena. Direct contact with the respondent while asking questions made it possible to deepen specific thematic issues, and also gave the respondent the opportunity to develop and justify his statements. The interview was conducted in the places where the surveyed companies have their headquarters.

The research also used the CATI interview method. This type of research method makes it possible to carry out research on large, targeted samples in a short time and at low costs. In addition to the CATI method, the study also used the CAWI method, in which the respondent was asked to fill in a research questionnaire in an electronic form included in web application. The CAWI method, as in the case of the previous method, also makes it possible to conduct tests on very large samples, in a short time and at low test costs. In addition, the advantage of this method is the anonymity of the respondent, and thus freedom in answering, for example, questions about the amount of earnings. The overall aim of the methods used was to get to know the facts and capture as many details as possible in relation to the questions posed. The research was carried out on a random sample of 109 enterprises. The response rate was $68 \%$, which is 74 companies.

The tool used to conduct the research was a research questionnaire containing an ordered list of questions. It covered questions about four areas of marketing mix - product, price, distribution and mix promotion. The research used a seven-point version of the Likert scale in order to increase the accuracy of the measurement.

\section{SWOT Analysis Results}

The data obtained as a result of the research study made it possible to analyse the individual elements of the marketing mix. Tables 1, 2, 3 and 4 present a SWOT analysis on the elements of sustainable marketing mix in food industry enterprises. 
Table 1. SWOT analysis -sustainable product

\begin{tabular}{|c|c|c|c|}
\hline \multicolumn{4}{|c|}{ Sustainable Product-PRO } \\
\hline \multicolumn{2}{|r|}{ Strengths } & \multicolumn{2}{|c|}{ Weaknesses } \\
\hline $\begin{array}{l}\text { PRO } \\
-\mathrm{S} 1\end{array}$ & $\begin{array}{l}\text { Companies } \\
\text { design products } \\
\text { taking into } \\
\text { account their } \\
\text { impact on the } \\
\text { natural } \\
\text { environment }\end{array}$ & $\begin{array}{l}\text { PRO } \\
-\mathrm{W} 1\end{array}$ & $\begin{array}{l}\text { Enterprises do } \\
\text { not use } \\
\text { packaging made } \\
\text { from fully or } \\
\text { partially } \\
\text { recycled raw } \\
\text { materials }\end{array}$ \\
\hline $\begin{array}{l}\text { PRO } \\
-\mathrm{S} 2\end{array}$ & $\begin{array}{l}\text { Companies } \\
\text { design products } \\
\text { taking into } \\
\text { account their } \\
\text { impact on the } \\
\text { health of } \\
\text { consumers }\end{array}$ & & \\
\hline $\begin{array}{l}\text { PRO } \\
-\mathrm{S} 3\end{array}$ & $\begin{array}{l}\text { Companies save } \\
\text { energy, water } \\
\text { and fuel needed } \\
\text { for production }\end{array}$ & & \\
\hline $\begin{array}{l}\text { PRO } \\
-\mathrm{S} 4\end{array}$ & $\begin{array}{l}\text { Companies } \\
\text { effectively } \\
\text { manage human } \\
\text { capital while } \\
\text { respecting } \\
\text { employee rights }\end{array}$ & & \\
\hline \multicolumn{2}{|c|}{$\begin{array}{l}\text { Development } \\
\text { opportunities }\end{array}$} & \multicolumn{2}{|c|}{ Development threats } \\
\hline $\begin{array}{l}\text { PRO } \\
-\mathrm{O} 1\end{array}$ & $\begin{array}{l}\text { Enterprises are } \\
\text { gradually } \\
\text { reducing the } \\
\text { types and } \\
\text { quantities of } \\
\text { materials used } \\
\text { to produce } \\
\text { packaging, e.g. } \\
\text { foil, paper, } \\
\text { plastic, } \\
\text { aluminium, etc. }\end{array}$ & $\begin{array}{l}\text { PRO } \\
-\mathrm{T} 1\end{array}$ & $\begin{array}{l}\text { Enterprises do } \\
\text { not intend to use } \\
\text { renewable } \\
\text { sources }\end{array}$ \\
\hline $\begin{array}{l}\mathrm{PRO} \\
-\mathrm{O} 2\end{array}$ & $\begin{array}{l}\text { Enterprises } \\
\text { gradually reduce } \\
\text { the emission of } \\
\text { harmful gases, } \\
\text { dusts, } \\
\text { fragrances, } \\
\text { industrial } \\
\text { wastewater, and } \\
\text { the generation } \\
\text { of production } \\
\text { waste }\end{array}$ & $\begin{array}{l}\text { PRO } \\
-\mathrm{T} 2\end{array}$ & $\begin{array}{l}\text { The companies } \\
\text { do not intend to } \\
\text { introduce } \\
\text { modifications to } \\
\text { create } \\
\text { ecological } \\
\text { packaging }\end{array}$ \\
\hline $\begin{array}{l}\mathrm{PRO} \\
-\mathrm{O} 3\end{array}$ & $\begin{array}{ll}\text { Enterprises } & \text { are } \\
\text { gradually } & \\
\text { reducing } & \text { the }\end{array}$ & $\begin{array}{l}\text { PRO } \\
-\mathrm{T} 3\end{array}$ & $\begin{array}{ll}\text { Activities } & \text { of } \\
\text { competitive } \\
\text { companies }\end{array}$ \\
\hline
\end{tabular}

\begin{tabular}{|l|l|l|}
\hline $\begin{array}{l}\text { content of such } \\
\text { raw materials } \\
\text { as: white sugar, } \\
\text { chemical } \\
\text { preservatives } \\
\text { and } \\
\text { preservatives, } \\
\text { flavour } \\
\text { enhancers, } \\
\text { artificial the area of } \\
\text { colours, trans } \\
\text { fats, etc. }\end{array}$ & & \\
production \\
\hline
\end{tabular}

Source: Own study

Taking into account the first element of the marketing mix, i.e. the product, it can be concluded that enterprises are engaged in activities aimed at introducing to the market food products that are characterised by the characteristics of sustainability. Regarding the product, four strengths of sustainable product development (PRO-S), one weakness (PRO$\mathrm{W})$, three opportunities (PRO-O) and three threats (PRO-T) have been identified.

Table 2.SWOT analysis -sustainable price

\begin{tabular}{|c|c|c|c|}
\hline \multicolumn{4}{|c|}{ Sustainable Price-(PRI) } \\
\hline \multicolumn{2}{|r|}{\begin{tabular}{l}
\multicolumn{1}{c}{ Sustainable I } \\
Strengths
\end{tabular}} & \multicolumn{2}{|c|}{ Weaknesses } \\
\hline $\begin{array}{l}\text { PRI } \\
-S 1\end{array}$ & $\begin{array}{l}\text { Enterprises in the } \\
\text { prices of products } \\
\text { take into account } \\
\text { the costs of } \\
\text { purchasing raw } \\
\text { materials and } \\
\text { materials for } \\
\text { production }\end{array}$ & $\begin{array}{l}\text { PRI - } \\
\text { W1 }\end{array}$ & $\begin{array}{l}\text { Enterprises do } \\
\text { not take into } \\
\text { account labour } \\
\text { costs in their } \\
\text { product prices, } \\
\text { e.g. } \\
\text { occupational } \\
\text { health and } \\
\text { safety, social } \\
\text { welfare }\end{array}$ \\
\hline $\begin{array}{l}\text { PRI } \\
- \text { S2 }\end{array}$ & $\begin{array}{l}\text { Enterprises } \\
\text { include the costs } \\
\text { of transporting } \\
\text { and storing } \\
\text { products in their } \\
\text { product prices }\end{array}$ & & \\
\hline $\begin{array}{l}\text { PRI } \\
-\mathrm{S} 3\end{array}$ & $\begin{array}{l}\text { Enterprises take } \\
\text { into account } \\
\text { labour costs in the } \\
\text { prices of products, } \\
\text { e.g. ensuring } \\
\text { occupational } \\
\text { health and safety, } \\
\text { social welfare }\end{array}$ & & \\
\hline & $\begin{array}{l}\text { Development } \\
\text { opportunities }\end{array}$ & \multicolumn{2}{|c|}{ Development threats } \\
\hline PRI & Increased & PRO & In their product \\
\hline
\end{tabular}




\begin{tabular}{|c|c|c|c|}
\hline \multirow[t]{3}{*}{$-\mathrm{O} 1$} & $\begin{array}{l}\text { consumer interest } \\
\text { in the purchase of } \\
\text { environmentally } \\
\text { friendly food } \\
\text { products }\end{array}$ & $-\mathrm{T} 1$ & $\begin{array}{l}\text { prices, } \\
\text { enterprises do } \\
\text { not intend to } \\
\text { take into } \\
\text { account the } \\
\text { costs associated } \\
\text { with reducing } \\
\text { the emission of } \\
\text { harmful gases, } \\
\text { dusts, } \\
\text { fragrances, } \\
\text { industrial } \\
\text { wastewater, } \\
\text { and production } \\
\text { waste. }\end{array}$ \\
\hline & & $\begin{array}{l}\text { PRO } \\
- \text { T2 }\end{array}$ & $\begin{array}{l}\text { Enterprises do } \\
\text { not intend to } \\
\text { include } \\
\text { packaging } \\
\text { recycling costs } \\
\text { in their product } \\
\text { prices }\end{array}$ \\
\hline & & $\begin{array}{l}\text { PRO } \\
- \text { T3 }\end{array}$ & $\begin{array}{l}\text { In their product } \\
\text { prices, } \\
\text { enterprises do } \\
\text { not intend to } \\
\text { take into } \\
\text { account the } \\
\text { costs of } \\
\text { treatment } \\
\text { related to the } \\
\text { consumption of } \\
\text { food products, } \\
\text { e.g. the costs of } \\
\text { treating } \\
\text { obesity, } \\
\text { diabetes, tooth } \\
\text { decay, etc. }\end{array}$ \\
\hline
\end{tabular}

Source: Own study

The second element of the marketing mix that was analysed is the price. In this case, it can be seen that the price has three strong trait of sustainable price development (PRI - S), one weak trait (PRI $\mathrm{W})$, one opportunity to develop sustainable prices (PRI - O) and three threats to sustainable product pricing. food (PRI $-\mathrm{T})$.

Table 3.SWOT analysis -Sustainable distribution

\begin{tabular}{|l|l|l|lr|}
\hline \multicolumn{4}{|c|}{ Sustainable Distribution-(DIS) } \\
\hline \multicolumn{3}{|c|}{ Strengths } & \multicolumn{3}{|c|}{ Weaknesses } \\
\hline DIS & $\begin{array}{l}\text { Enterprises } \\
\text { - S1 }\end{array}$ & optimize pIS & Enterprises do duct \\
& $\begin{array}{l}\text { deliveries by } \\
\text { choosing the right }\end{array}$ & W1 & $\begin{array}{l}\text { not } \\
\text { environmentally } \\
\text { friendly means of }\end{array}$ \\
\hline
\end{tabular}

\begin{tabular}{|c|c|c|c|}
\hline & $\begin{array}{l}\text { route (shorter, } \\
\text { faster routes) }\end{array}$ & & $\begin{array}{l}\text { transport, } \\
\text { hybrid } \\
\text { electric } \\
\text { LPG-fuelled } \\
\text { cars, } \\
\text { etc. }\end{array}$ \\
\hline $\begin{array}{l}\text { DIS } \\
- \text { S2 }\end{array}$ & $\begin{array}{l}\text { Enterprises } \\
\text { combine } \\
\text { deliveries to } \\
\text { several recipients } \\
\text { simultaneously }\end{array}$ & $\begin{array}{l}\text { DIS } \\
- \\
\text { W2 }\end{array}$ & $\begin{array}{ll}\text { Enterprises do } \\
\text { not optimise } \\
\text { distribution } \\
\text { channels by } \\
\text { reducing } \\
\text { intermediaries } \\
\text { involved in } \\
\text { distribution } \\
\text { processes }\end{array}$ \\
\hline $\begin{array}{l}\text { DIS } \\
- \text { S3 }\end{array}$ & $\begin{array}{l}\text { Enterprises adjust } \\
\text { the means of } \\
\text { transport to the } \\
\text { amount of } \\
\text { transported goods }\end{array}$ & & \\
\hline $\begin{array}{l}\text { DIS } \\
- \text { S4 }\end{array}$ & $\begin{array}{l}\text { Enterprises } \\
\text { maximise the use } \\
\text { of transport space } \\
\text { by proper } \\
\text { arrangement } \\
\text { products } \\
\text { means in } \\
\text { transport }\end{array}$ & & \\
\hline $\begin{array}{l}\text { DIS } \\
- \text { S5 }\end{array}$ & $\begin{array}{l}\text { Enterprises } \\
\text { monitor and } \\
\text { control drivers' } \\
\text { working time in } \\
\text { order to avoid } \\
\text { road accidents }\end{array}$ & & \\
\hline $\begin{array}{l}\text { DIS } \\
- \text { S6 }\end{array}$ & $\begin{array}{l}\text { Enterprises use } \\
\text { environmentally } \\
\text { friendly resources } \\
\text { and devices }\end{array}$ & & \\
\hline \multicolumn{2}{|c|}{ Development chances } & \multicolumn{2}{|c|}{ Development threats } \\
\hline $\begin{array}{l}\text { DIS } \\
- \text { O1 }\end{array}$ & $\begin{array}{l}\text { Companies } \\
\text { intend to phase } \\
\text { out means of } \\
\text { transport with } \\
\text { high emissions } \\
\text { and noise }\end{array}$ & $\begin{array}{l}\text { DIS } \\
-\mathrm{T} 1\end{array}$ & $\begin{array}{l}\text { Enterprises do } \\
\text { not intend to } \\
\text { select } \\
\text { intermediaries in } \\
\text { terms of } \\
\text { environmental } \\
\text { and social } \\
\text { sensitivity }\end{array}$ \\
\hline
\end{tabular}

Source: Own study

Carrying out further considerations in the area of SWOT analysis of the sustainable marketing of the mix of food products, one should refer to another element, which is distribution. In this case, the results of the analysis indicate as many as six strengths of the implementation of sustainable 
distribution of food products (DIS-S), while two weak features of sustainable distribution (DIS-W) have been identified. One development opportunity (DIS-O) and one threat (DIS-T) in achieving sustainable distribution have also been identified.

Table 4. SWOT analysis -Sustainable promotion

\begin{tabular}{|c|c|c|c|}
\hline \multicolumn{4}{|c|}{$\begin{array}{c}\text { Sustainable Promotion (Communication)- } \\
\text { (COM) }\end{array}$} \\
\hline \multicolumn{2}{|r|}{ Strengths } & \multicolumn{2}{|c|}{ Weaknesses } \\
\hline $\begin{array}{l}\mathrm{COM} \\
-\mathrm{S} 1\end{array}$ & $\begin{array}{l}\text { Enterprises post } \\
\text { the content of } \\
\text { promotional } \\
\text { messages that is } \\
\text { transparent and } \\
\text { credible }\end{array}$ & $\begin{array}{l}\text { COM } \\
-\mathrm{W} 1\end{array}$ & $\begin{array}{l}\text { Enterprises do } \\
\text { not publish } \\
\text { promotional } \\
\text { messages that } \\
\text { are educational } \\
\text { in nature }\end{array}$ \\
\hline $\begin{array}{l}\mathrm{COM} \\
-\mathrm{S} 2\end{array}$ & $\begin{array}{l}\text { Enterprises post } \\
\text { promotional } \\
\text { messages via the } \\
\text { Internet } \\
\text { (banners, } \\
\text { advertisements) }\end{array}$ & $\begin{array}{l}\text { COM } \\
- \text { W2 }\end{array}$ & $\begin{array}{l}\text { Enterprises do } \\
\text { not publish } \\
\text { promotional } \\
\text { messages that } \\
\text { emphasize pro- } \\
\text { ecological and } \\
\text { pro-social } \\
\text { features of } \\
\text { product }\end{array}$ \\
\hline \multicolumn{2}{|c|}{ Development chances } & \multicolumn{2}{|c|}{ Development threats } \\
\hline $\begin{array}{l}\text { COM } \\
-\mathrm{O} 1\end{array}$ & $\begin{array}{l}\text { Enterprises } \\
\text { intend to resign } \\
\text { from publishing } \\
\text { announcements } \\
\text { in the form of } \\
\text { press articles, } \\
\text { brochures and } \\
\text { promotional } \\
\text { leaflet }\end{array}$ & $\begin{array}{l}\mathrm{COM} \\
-\mathrm{T} 1\end{array}$ & $\begin{array}{l}\text { Enterprises do } \\
\text { not intend to } \\
\text { post } \\
\text { promotional } \\
\text { messages that } \\
\text { inform } \\
\text { consumers } \\
\text { about the } \\
\text { ecological and } \\
\text { social activity } \\
\text { of the } \\
\text { enterprise }\end{array}$ \\
\hline & & $\begin{array}{l}\mathrm{COM} \\
-\mathrm{T} 2\end{array}$ & $\begin{array}{l}\text { Enterprises do } \\
\text { not intend to } \\
\text { post } \\
\text { promotional } \\
\text { messages that } \\
\text { encourage the } \\
\text { purchase of } \\
\text { pro-ecological } \\
\text { and pro-social } \\
\text { products } \\
\text { manufactured } \\
\text { by the } \\
\text { company }\end{array}$ \\
\hline
\end{tabular}

\section{Source: Own study}

The last, fourth element of the marketing mix that was investigated is the promotion/communication of food industry enterprises. With regard to corporate communication, two strengths of the development of sustainable communication (COM-S) and two weaknesses of communication (COM-W) can be identified. The situation is similar in terms of opportunities and threats. As a result of the analysis, one development opportunity (COM-O) and two threats that occur in the implementation of sustainable promotion/communication (COM-T) were identified.

To better illustrate the conducted analysis, the results are presented graphically in Figure 1.

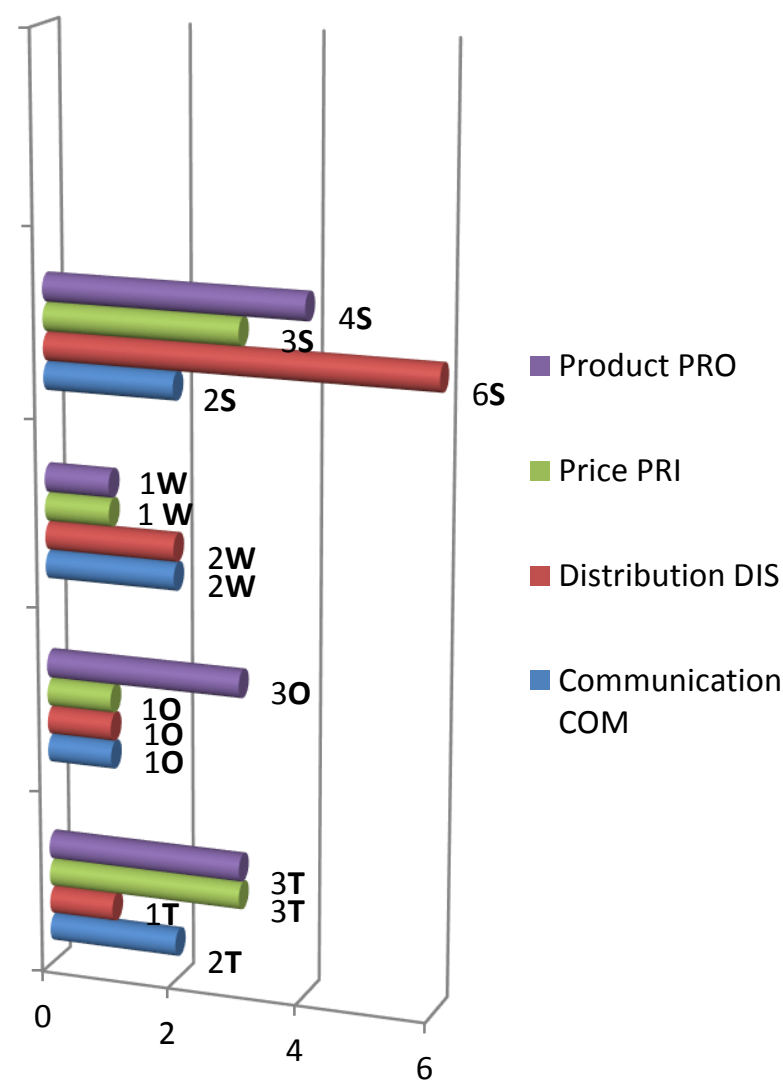

Fig. 1: SWOT analysis of sustainable marketing mix of enterprises in food industry.

\section{Conclusion}

The reason for the subject matter of the study is the rapidly progressing degradation of the natural environment caused by the economic activity of production companies, including the food sector. The negative effects of the economic activity of enterprises contribute not only to the degradation of the ecological 
environment, but also to the emergence of social problems [21].

A production company that wants to define itself as a sustainable organisation should first adopt the principles of sustainable development, and then implement them in the individual organisational structures of the company. Employee personnel is an important factor that determines the company's success in conducting sustainable economic activity. Especially senior management is the body that defines the mission and goals of the organisation focused on the sustainable conduct of the entire company, with particular emphasis on the concept of the marketing mix [22].

The conducted SWOT analysis allowed to identify the features that may have a significant impact on the development of a sustainable marketing mix in food industry enterprises in Poland. The results of the analysis indicate which areas of the marketing mix are characterised by sustainability features and which require improvement and refinement.

SWOT analysis covers four elements of the marketing mix, i.e. product, price, distribution and promotion mix, but according to the author of this study, one should not forget about the fifth element, which is the aforementioned staff. The theoretical considerations, conclusions and analysis of the research results included in the study do not fully solve the subject matter. Therefore, it remains an open question to search for new and creative solutions aimed at reconciling the economic development of food industry enterprises, as well as other economic entities, with ecological and social values. The article may support enterprises that strive for a balance between the company's activities aimed at achieving financial goals and the environmental and social environment.

\section{References:}

[1] Rudawska E., Sustainable marketing strategy in food and drink industry: A comparative analysis of B2Band B2C SMEs operating in Europe, Journal of Business \&Industrial Marketing, vol. 34, 2019, pp. 875-890.

[2] Ulvenblad P., Ulvenblad P., Tell J., An overview of sustainable business models for innovation in Swedishagri-food production,
Journal of Integrative Environmental Sciences, vol.16, 2019, pp. 1-22.

[3] Agrawal A. K., Kumar D., Rahman Z., An ISM approach for modelling the enablers of sustainability inmarket-oriented firms. International, Journal of Business Excellence, vol. 12, 2017, pp. 23-45.

[4] Pomering A., Johnson L. W., Building Sustainability into Services Marketing: Expanding Decision-Making from a Mix to a Matrix. Sustainability, vol. 10, 2018, p. 2992.

[5] Fuller D. Sustainable marketing. ManagerialEcological, SAGE Publications Inc., 1999.

[6] Belz F., Peattie K., Sustainability Marketing. A Global Perspective, J. Wiley\&Sons, 2010.

[7] Leitner, K. Balanced sustainability marketing, Sudwestdeutscher Verlag fur Hochschulschriften, 2010.

[8] Kadirov D. Sustainability marketing systems, VDM Verlag Dr. Muller, 2010.

[9] Martin D., Schouten J. Sustainability marketing, Prentice Hall, 2012.

[10] Emery B. Sustainable marketing, Pearson Education Limited, 2012.

[11] Kemper J., Hall C. M., Ballantine, P. W. Marketing and Sustainability: Business as Usual or Changing Worldviews? Sustainability, vol. 11, 2019, p. 780.

[12] Trojanowski, T. Marketing mix produktów cukierniczych oparty na zasadach zrównoważonego rozwoju, Difin, 2018.

[13] Kazibudzki, P. T., Trojanowski, T. Examination of marketing mix performance in relation to sustainable development of the Poland's confectionery industry, PloS ONE, vol. 15, no. 10, 2020.

[14] Galati F., Bigliardi B., Petroni, A., Pinna, C., Rossi, M., Terzi, S. Sustainable Product Lifecycle: The Role of ICT. Sustainability, vol. 11, no. 24, 2019, p. 7003.

[15] Hauschild M., Jeswiet, J., Alting, L. From Life Cycle Assessment to Sustainable Production: Status and Perspectives. CIRP Annals: Manufacturing Technology, vol. 54, 2005, pp. 1-21.

[16] Trojanowski T., Sustainable product prices, Przedsiębiorczość i Zarządzanie, vol.18, no.11, 2017, pp. 97-205.

[17] Zou G. L., Chau, K. W. Determinants and Sustainability of House Prices: The Case of 
Shanghai, China. Sustainability, vol. 7, 2015, pp. 4524-4548.

[18] Todorovic V., Maslaric. M., Bojic S., Jokic M., Mircetic, D., Nikolicic, S. Solutions for More Sustainable Distribution in the Short Food Supply Chains, Sustainability, vol.10, no. 10,2018 , p. 3481.

[19] Liu S., Xu J., Shi X., Li G., Liu D. Sustainable Distribution Organization Based on the Supply - Demand Coordination in Large Chinese Cities. Sustainability, vol. 10, no. 9, 2018, p. 3042.

[20] Chung J. Effect of Quality Uncertainty, Regulatory Focus, and Promotional Strategies on Perceived Savings for Sustainable Marketing. Sustainability, vol. 12, no. 14, 2020, p. 5653.

[21] Zaremba-Warnke, S. Marketing jako narzędzie realizacji ścieżek strategicznych ekonomii zrównoważonego rozwoju, Rocznik Ochrona Środowiska, vol. 15, no.3, 2013, pp. 28502862.

[22] Trojanowski, T. The Attitudes of Managers Towards the Concept of Sustainable Development in Polish Food Industry Enterprises, Rocznik Ochrona Środowiska, vol.22, no. 2, 2020, pp. 622-634.

\section{Creative Commons Attribution License}

4.0(Attribution 4.0 International, CC BY 4.0)

This article is published under the terms of the Creative Commons Attribution License 4.0

https://creativecommons.org/licenses/by/4.0/deed.en _US 